Volume 36 | Issue 1

2004

\title{
Mediating Interactions in an Expanding International Intellectual Property Regime
}

Laurence R. Helfer

Follow this and additional works at: https://scholarlycommons.law.case.edu/jil

Part of the International Law Commons

\section{Recommended Citation}

Laurence R. Helfer, Mediating Interactions in an Expanding International Intellectual Property Regime, 36 Case W. Res. J. Int'l L. 123 (2004)

Available at: https://scholarlycommons.law.case.edu/jil/vol36/iss1/6

This Article is brought to you for free and open access by the Student Journals at Case Western Reserve University School of Law Scholarly Commons. It has been accepted for inclusion in Case Western Reserve Journal of International Law by an authorized administrator of Case Western Reserve University School of Law Scholarly Commons. 


\title{
MEDIATING INTERACTIONS IN AN EXPANDING INTERNATIONAL INTEllectual Property Regime
}

\author{
Laurence R. Helfer ${ }^{\dagger}$
}

The last few years have been a particularly heady period for governments, private parties, and non-governmental organizations ("NGOs") seeking to develop new rules to regulate intellectual property ("IP") protection standards. During that time, a slew of lawmaking initiatives, studies, and reports have been launched in a strikingly large number of international venues. Work on intellectual property rights is now underway in intergovernmental organizations such as the World Trade Organization ("WTO"), World Intellectual Property Organization ("WIPO"), and Food and Agriculture Organization ("FAO"); in negotiating fora such as the Convention on Biological Diversity ("CBD") and its Conference of the Parties and the Commission on Genetic Resources for Food and Agriculture; and in United Nations expert and political bodies such as the Commission on Human Rights and the High Commissioner for Human Rights. ${ }^{1}$ In some of these venues, IP lawmaking has involved the negotiation of new international agreements. In others, IP norms are being generated through the reinterpretation of existing treaties or the creation of nonbinding guidelines, resolutions, and other forms of soft law.

This essay views these myriad developments through the lens of the international relations theory of regimes. ${ }^{3}$ It uses the insights of regime theory to make three basic points. First, it explains why IP lawmaking has broken out of the confined institutional spaces of established international IP fora, such as WIPO and the WTO, and has expanded into a broad and

\footnotetext{
$\dagger$ Professor of Law, Vanderbilt University Law School. An earlier version of this essay was presented at the Conference on the Future of the International Intellectual Property at Case Western Reserve University School of Law, held on March 26, 2004. My thanks to Peter Gerhart for inviting me to present a paper at the conference. (C) 2004, Laurence R. Helfer.

${ }^{1}$ For a detailed analysis of these developments, see Laurence R. Helfer, Regime Shifting: The TRIPS Agreement and New Dynamics of International Intellectual Property Lawmaking, 29 YALE J. INT'L L. 1, 23-47 (2004) [hereinafter Helfer, Regime Shifting].

${ }^{2}$ For illuminating discussions of the role of nonbinding norms in international law, see COMMITMENT AND COMPLIANCE: THE ROLE OF NON-BINDING NORMS IN THE INTERNATIONAL LEGAL SYSTEM (Dinah Shelton ed., 2000). For an international relations perspective on soft law, see Kenneth W. Abbott \& Duncan Snidal, Hard and Soft Law in International Governance, 54 INT'L ORG. 421 (2000).

${ }^{3}$ See generally ANDREAS HASENCLEVER ET AL., THEORIES OF INTERNATIONAL REgIMES 108 (1997); INTERNATIONAL REGIMES (Stephen D. Krasner ed., 1983); Stephan Haggard \& Beth A. Simmons, Theories of International Regimes, 41 INT'L ORG. 491 (1987).
} 
growing array of other international venues in environmental law, human rights, and public health. ${ }^{4}$ Second, it shows how this recent expansion helps to enrich regime theory itself by illustrating how regimes evolve over time and how they interact with institutions and actors in other issue areas. And third, it describes a working typology of the different modes of interaction that are developing among the many international venues in which IP lawmaking is now occurring.

\section{International Regimes and Intellectual Property Protection Standards}

Regime theory was developed by political scientists in the early $1980 \mathrm{~s}$ in reaction to the then-dominant realist paradigm of international relations. Realist scholars assert that international rules and international institutions are epiphenomenal - that is, they exert no independent influence on the behavior of nation states. ${ }^{8}$ In response to realists' claims that these rules and institutions were all but irrelevant to how nations behave, regime theorists sought to demonstrate that states can derive substantial benefits from cooperating under conditions of relative anarchy. These benefits include reducing transaction costs, creating property rights, increasing access to information, monitoring state behavior, mediating disputes, and sanctioning noncompliance.

In addition to identifying the causal factors that could lead selfinterested states to create international regimes, these early regime theorists made two principal contributions to understanding how nations behave. First, they revealed that states satisfy their demand for international rules and institutions not only through legally binding treaties and formal organizations, but also through softer forms of interaction, such as nonbinding declarations and informal government networks. Thus, Stephen Krasner's foundational article, Structural Causes and Regime Consequences, defined regimes as "sets of implicit or explicit principles, norms, rules, and decision-making procedures around which actors'

\footnotetext{
${ }^{4}$ See infra Part I.

${ }^{5}$ See infra Part II.

${ }^{6}$ See infra Part III.

${ }^{7}$ See generally, RoBERT O. KEOHANE, AFTER HEgEMONY: COOPERATION AND DISCORD IN THE WORLD POLITICAL ECONOMY (1984).

${ }^{8}$ See, e.g., Claire R. Kelly, Realist Theory and Real Constraints, 44 VA. J. INT'L L. 545, 562-64 \& n.92 (2004).

${ }^{9}$ See William J. Aceves, Institutionalist Theory and International Legal Scholarship, 12 AM. U. J. INT'L L. \& POL'Y 227, 240-56 (1997) (reviewing the benefits of state cooperation through international institutions); see also KEOHANE, supra note 7, at 107 (stating that the "most important function" of regimes "is to facilitate negotiations leading to mutually beneficial agreements among governments").
} 
expectations converge in a given area of international relations." ${ }^{\prime 10}$ This conceptual framework for analyzing interstate cooperation was far more capacious than the rule-orientated, doctrinal approaches favored by international legal scholars.

Regime theorists also had a second goal-to explore whether regimes, once formed, actually altered state behavior. Because regimes are created by states, it would be logical to assume that they could survive only so long as their benefits outweighed their costs to the governments involved. But political scientists showed that international regimes are often sticky. Their sunk costs, and the time and effort needed to create alternative institutions, discourage states - even powerful ones-from killing off or abandoning those regimes already in existence. ${ }^{11}$ In the language of international relations theory, this stickiness causes regimes to function as "intervening variables" that independently influence state bargaining patterns and their resulting policy outcomes. ${ }^{12}$

Given the constraints that regimes impose, what strategies have states and non-state actors used to tailor existing regimes to more accurately reflect their interests? One important strategy is "regime shifting," i.e. "an attempt to alter the status quo ante by moving treaty negotiations, lawmaking initiatives, or standard setting activities from one international venue to another."13

In the area of intellectual property, the most well known example of regime shifting is the successful effort by the United States and the European Communities ("EC") to move certain IP protection standards from WIPO to the WTO, a move manifested in the Agreement on TradeRelated Aspects of Intellectual Property Rights ("TRIPS"). ${ }^{14}$ But the strategy of IP regime shifting has many earlier antecedents, such as the United States' promotion of the Universal Copyright Convention as an alternative to the Berne Convention in the 1950 s, ${ }^{15}$ or developing countries'

10 Stephen D. Krasner, Structural Causes and Regime Consequences: Regimes as Intervening Variables, in INTERNATIONAL REgIMES 1, 2 (Stephen D. Krasner ed., 1983) (emphasis added).

11 KeOHANE, supra note 7, at 102 (discussing ways in which international regimes embody "sunk costs" for states that explains "why they persist even when all members would prefer somewhat different mixtures of principles, rules, and institutions").

${ }^{12}$ Krasner, supra note 10 , at 1 .

${ }^{13}$ Helfer, Regime Shifting, supra note 1, at 14.

${ }^{14}$ Agreement on Trade-Related Aspects of Intellectual Property Rights, Apr. 15, 1994, Marrakesh Agreement Establishing the World Trade Organization, Annex 1C, LEGAL INSTRUMENTS-RESULTS OF THE URUGUAY ROUND, 33 I.L.M. 1197 (1994) [hereinafter TRIPS].

${ }^{15}$ See Barbara A. Ringer, The Role of the United States in International Copyright-Past, Present, and Future, 56 GEO. L.J. 1050, 1060-65 (1968) (discussing the history of the Universal Copyright Convention and its ratification by the United States). 
campaign to establish a "New World Information and Communications Order" in UNESCO in the 1970s. ${ }^{16}$

The unqualified success of the United States and EC in linking international trade and intellectual property rights in TRIPS has encouraged scholars such as Peter Drahos to argue that regime shifting is a game that only powerful nations can play. ${ }^{17}$ In fact, however, the post-TRIPS era has seen the emergence of a less well known second wave of regime shifting, this time by weaker developing countries that are increasingly dissatisfied with many provisions in TRIPS (or its omission of other issues) and are actively seeking out ways to recalibrate or supplement the treaty by relocating IP lawmaking initiatives to other international venues. ${ }^{18}$

\section{Revising Regime Theory: Evolution of and Interaction among Regimes and the Strategy of Regime Shifting}

The existence of regime shifting by both powerful and weaker states raises intriguing questions. For example, exactly how could a strategy of regime shifting allow developing countries and their NGO allies to mount challenges to the TRIPS Agreement? And what did these states and nonstate actors hope to achieve by developing new intellectual property norms in fora not previously concerned with the products of human creativity or innovation?

Regime theory offers only limited guidance to answer these questions. In particular, the existing literature on how regimes evolve over time is under-theorized. Such limited writings as exist assume that each international regime is discrete and governs only a single issue area (such as trade or human rights) without formal or informal relationships to other regimes. ${ }^{19}$ What regime theorists have not fully considered is how actors respond when these clear boundary lines begin to erode through linkages of

\footnotetext{
${ }^{16}$ Peter Billing et al., State Characteristics and Foreign Policy: Industrialized Countries and the UNESCO Crisis, 28 COOPERATION \& CONFLICT 143, 143-44; see also JOHN Braithwaite \& Peter Drahos, Global Business Regulation 569 (2000) (noting influence of developing countries in UNESCO, and quoting UNESCO official who stated that "the organization tended to consider the issue of copyright from the perspective of users").

${ }^{17}$ Cf. BRAITHWAItE \& DraHos, supra note 16, at 565 (stating that "forum-shifting is a strategy that only the powerful and well-resourced can use").

${ }^{18}$ See Helfer, Regime Shifting, supra note 1, at 53-62.

${ }^{19}$ Robert O. Keohane \& Joseph S. Nye, Jr., The Club Model of Multilateral Cooperation and Problems of Democratic Legitimacy, in EFFICIENCY, EQUITY, AND LEGITIMACY: THE Multilateral Trading System at the MillenNium 264, 266 (Roger B. Porter et al. eds., 2001).
} 
formerly distinct regulatory subjects. ${ }^{20}$ With the growing prevalence and importance of these linkages, even less powerful states and non-state actors are becoming more adept at strategically shifting negotiations to those international venues that better serve their interests.

To flesh out these theoretical points, consider first what post-TRIPS intellectual property regime shifting could not do. It could not, at least as a formal matter, alter the obligation of developing countries to implement TRIPS standards into their national laws. Nor could it function as a back door way to denounce TRIPS (or, to be more precise, the Final Act Embodying the Results of the Uruguay Round of Multilateral Trade Negotiations to which TRIPS is annexed). ${ }^{22}$ To the contrary, developing countries remain at risk of WTO dispute settlement proceedings-and WTO trade sanctions-if they fail to adopt the IP protection rules that TRIPS requires. But if regime shifting strategy could not directly undermine TRIPS, it could be used indirectly, first to generate what international relations scholars have referred to as "counterregime norms," and then to integrate those revisionist norms into the WTO and WIPO. ${ }^{23}$

The value of counterregime norms for developing countries is grounded in two fundamental characteristics of the international legal system. The first is the disaggregated and nonhierarchical structure of that system, and the second is the frequent use of nonbinding norms to guide the behavior of states and private parties.

With only a few exceptions, there are no clear hierarchies among international legal rules. Nor is there a supreme international judicial body or legislature with the power to comprehensively reconcile inconsistent rules or balance competing policy goals. ${ }^{24}$ The absence of strong

${ }^{20}$ For illuminating discussions of linkages with an emphasis on the WTO, see generally David W. Leebron, Linkages, 96 AM. J. INT'L L. 5 (2002); Joel P. Trachtman, Institutional Linkage: Transcending “Trade and . .", 96 AM. J. INT'L L. 77 (2002).

${ }^{21}$ Helfer, Regime Shifting, supra note 1, at 16-17.

${ }^{22}$ See Final Act Embodying the Results of the Uruguay Round of Multilateral Trade Negotiations, Apr. 15, 1994, at art. XVI, para. 5, 33 I.L.M. 1140, 1143 (1994), available at http://www.wto.org/english/docs_e/legal_e/03-fa_e.htm.

${ }^{23}$ See Donald J. Puchala \& Raymond F. Hopkins, International Regimes: Lessons from Inductive Analysis, in INTERNATIONAL REGIMES 61, 66 (Stephen D. Krasner ed., 1983) (defining "counterregime norms" as norms formulated by the "disadvantaged participants" in a regime and "which either circulate in the realm of thetoric or lie dormant as long as those who dominate the existing regime preserve their power and their consequent ability to reward compliance and punish deviance"); Helfer, Regime Shifting, supra note 1, at 14 (defining "counterregime norms" as "binding treaty rules and nonbinding soft law standards that seek to alter the prevailing legal landscape" by "contest[ing] established normative orthodoxies").

${ }^{24}$ See Laurence R. Helfer, Constitutional Analogies in the International Legal System, 37 LOY. L.A. L. REV. 193, 205-213 (2003). 
hierarchies or of a centralized interpretive authority means that international lawmaking is often a messy business. But this messiness also creates strategic opportunities for states to advance competing approaches to the same subject in different international venues.

States often turn to soft law as a way to advance their preferred approach to a contested legal issue. At first, this claim may appear implausible. Why, after all, would states choose a method of lawmaking that by definition does not create legally binding commitments? But soft law can have advantages for governments, especially weaker governments, seeking hope to challenge the status quo. It is superficially less threatening to powerful states than hard treaty law. And it is easier and faster to create as compared to the often difficult and time-consuming process of negotiating new treaties. ${ }^{25}$

But over time, soft law can have hard-edged consequences. It can serve as a focal point for gathering and exchanging information. It can help to reshape interests and preferences. And it can generate a rich set of principles, norms, and rules to challenge existing legal paradigms. ${ }^{26}$

In the wake of TRIPS, developing countries used regime shifting in precisely these ways, exploiting the disaggregated, nonhierarchical structure of the international legal system to create new and sometimes inconsistent norms in different international fora. ${ }^{27}$ But developing governments did not stop at simply generating new rules and new conflicts. They used those rules and conflicts as the fuel for efforts to renegotiate legally binding intellectual property obligations in the WTO and WIPO.

Substantial empirical evidence supports this integrationist use of regime shifting. ${ }^{28}$ During the last three years, developing countries have used a variety of entry points in the WTO and WIPO to draft literally dozens of jointly authored proposals to modify intellectual property

${ }^{25}$ See Helfer, Regime Shifting, supra note 1, at 56-58, 72-75.

${ }^{26}$ Id. at 58-59.

${ }^{27}$ For informative discussions of how to reconcile conflicts among the rules of public international law with a focus on the WTO, see JOOST PAUWELYN, CONFLICT OF NORMS IN Public InTERnational LaW: How WTO LaW Relates to OtHer Rules of INTERNATIONAL LAW (2003); Gabrielle Marceau, A Call for Coherence in International Law: Praises for the Prohibition Against "Clinical Isolation" in WTO Dispute Settlement, J. WORLD TRADE, Oct. 1999 , at 87.

${ }^{28}$ See, e.g., World Trade Organization, Council for TRIPS, The Relationship Between the TRIPS Agreement and the Convention on Biological Diversity (CBD) - Checklist of Issues: Submission from Brazil, Cuba, Ecuador, Peru, Thailand, and Venezuela, WTO Doc. IP/C/W/420, at para. 2 (Mar. 2, 2004) (stating that "[m]ore than 25 communications and papers have been submitted by [WTO] Members on the" relationship between the CBD and TRIPS); see also Helfer, Regime Shifting, supra note 1, at 63-71 (providing additional empirical evidence of an integrationist regime shifting strategy used by developing countries). 
protection rules. These proposals were not generated in a vacuum; rather, they expressly rely on soft law resolutions, recommendations, and guidelines initially adopted in the environmental, public health, and human rights regimes. $^{29}$

This integrationist regime shifting strategy has also helped developing counties to increase their bargaining power within the WTO and WIPO. Coalescing their demands around proposals first generated in other regimes facilitated a proactive negotiating strategy in which governments worked in groups - like the "Group of 21 " that formed at last year's WTO Ministerial meeting in Cancun - and stuck to predetermined proposals for reform. ${ }^{30}$

Perhaps more importantly, reliance on these proposals changed the nature of developing countries' legal arguments. It allowed these countries to argue that the revision of intellectual property rules is not a selfinterested ploy to distort free trade or free ride on foreign creators or inventors, but rather part of a rational effort to harmonize nominally inconsistent legal obligations and normative objectives. This shifted the terms of the debate and allowed these countries to draw support from a wide array of actors and institutions to support their reform efforts. ${ }^{31}$

\section{Mediating Interactions among Actors and Institutions in an Expanding International Intellectual Property Regime}

So what has changed now that the principles, norms, and rules of intellectual property protection are being generated in multiple international venues? Treaty amendments, soft law standards, dispute settlement, and

${ }^{29}$ See, e.g., World Trade Organization, Council for TRIPS, The Relationship Between the TRIPS Agreement and the Convention on Biological Diversity and the Protection of Traditional Knowledge, WTO Doc. IP/C/W/356, at para. 11 (June 24, 2002).

${ }^{30}$ See The WTO Under Fire: Why Did the World Trade Talks in Mexico Fall Apart? And Who is to Blame?, ECONOMIST, Sept. 20, 2003, at 26-28; but see Peter Drahos, When the Weak Bargain with the Strong: Negotiations in the WTO 24-31 (2004) (unpublished manuscript, on file with the author) (noting the disadvantages as well as the advantages of group-based bargaining by developing counties in the WTO).

${ }^{31}$ Most notably, the European Communities and their member states have developed proposals to harmonize competing principles, norms, and rules that are sympathetic to developing countries' demands for reform. See, e.g., Communication from the Commission to the European Parliament and the Council, The Implementation by the EC of the "Bonn Guidelines" on Access to Genetic Resources and Benefit-sharing Under the Convention on Biological Diversity, COM(03)821 final, available at http://biodiversitychm.eea.eu.int/information/F1046684686/F1058442682/F1070869838/index_html?pp=1; European Commission Directorate-General for Trade, Communication by the European Communities and their Member States to the TRIPS Council on the Review of Article 27.3(b) of the TRIPS Agreement, and the Relationship Between the TRIPS Agreement and the Convention on Biological Diversity (CBD) and the Protection of Traditional Knowledge and Folklore: "A Concept Paper", (Sept. 12, 2002). 
national legislation are all important factors. But new interactions and linkages among actors and institutions merit special consideration. ${ }^{32}$ In the international intellectual property regime, these include: (1) granting the secretariat of one intergovernmental organization observer status in another organization, (2) establishing formal and informal partnerships between organizations to share information and lawmaking tasks; and (3) increasing cooperation and competition among actors and institutions engaged in intellectual property lawmaking. This section illustrates these points with a few examples.

\section{A. Observer Status in the TRIPS Council and in WIPO}

One way to influence intellectual property lawmaking is by participating as an observer in other intergovernmental organizations. Granting an intergovernmental organization "observer status" within a particular body of the WTO, for example, confers a defined set of privileges. Representatives of the organization may attend the meetings of the body, receive copies of all documents submitted to it, and may, upon invitation, address the body orally. ${ }^{33}$ The right to speak does not, however, "include the right to circulate papers or to make proposals ... . nor to participate in decision-making." 34 But although denied these important avenues of institutional voice, ${ }^{35}$ organizations with observer status will be on hand to provide legal and technical advice to governments both inside WTO negotiating rooms and in the all important hallways outside.

Given these potential avenues of influence, it is not surprising that applications for observer status have triggered significant political disputes in the WTO. Members often disagree over the propriety of granting such status to a particular organization, and the guidelines for granting such status are flexible enough to permit plausible competing arguments. ${ }^{36}$ The

${ }^{32}$ Interest in linkages has been especially acute for the WTO, which Jose Alvarez has described as a "linkage machine." José E. Alvarez, The WTO as Linkage Machine, 96 AM. J. INT'L L. 146 (2002).

${ }^{33}$ General Council, Guidelines for Observer Status for International Intergovernmental Organizations in the WTO, WT/L/161 (July 25, 1996) [hereinafter Guidelines for Observer Status].

${ }^{34}$ Id. at 98.

35 See Albert O. Hirschman, Exit, Voice, and Loyalty: Responses to Decline IN FIRMS, ORGANIZATIONS, AND STATES (1970).

${ }^{36}$ Guidelines for Observer Status, supra note 33, at 14 (requests for observer status are considered on a case-by-case basis, "taking into account such factors as the nature of work of the organization concerned, the nature of its membership, the number of WTO Members in the organization, reciprocity with respect to access to proceedings, documents and other aspects of observership, and whether the organization has been associated in the past with the work of [GATT]"). 
political debates on this issue have become especially acute after the November 2001 Doha Ministerial Conference, as WTO members debate the procedures to be used for negotiating revisions to WTO Agreements. ${ }^{37}$

This contentious atmosphere also pervades observer status applications to the TRIPS Council. The Council has granted observer status to the FAO and ad hoc observer status to the WHO, but applications from the Secretariat of the Convention on Biological Diversity ("CBD") since July 2000 have been repeatedly ignored. ${ }^{38}$ Opposition comes from the United States, which asserts that the CBD Secretariat does "not have a broad interest in TRIPS issues." 39 More recently, the United Nations High Commissioner for Human Rights, supported by the Sub-Commission for the Promotion and Protection of Human Rights, expressed the intention to apply for observer status. ${ }^{40}$

In comparison to the WTO, observer status in WIPO is significantly less politicized and easier to obtain. Not only are the formal criteria for granting observer status more open-ended than in the trade organization, ${ }^{41}$

${ }^{37}$ According to an April 2002 statement by then WTO Chairman Mike Moor, members have been unable to reach agreement on a number of observer status issues. Chairman Reports on Consultations About Acceding Countries' Participation, Observers, WTO NEWS (Apr. 17, 2002), available at http://www.wto.org/english/news_e/news02_e/ tnc_24april02_e.htm (last visited Oct. 6, 2004) (arguing in favor of observer status as a way to promote "efficiency, transparency and coherence" of WTO lawmaking).

${ }^{38}$ See Annual Report (2002) of the Council for TRIPS, IP/C/27, at para. 3 (Dec. 6, 2002) (listing intergovernmental organizations granted TRIPS observer status); TRIPS Council Meeting Ends in Gridlock, BRIDGES WKLY NEws DIG. (Int'l Ctr. for Trade \& Sustainable Dev., Geneva, Switzerland), July 4, 2000 (noting TRIPS Council's grant of WHO's application for ad hoc observer status and stating that applications from other international organizations, including CBD, remain pending); see also Convention on Biodiversity, Decision VI/24, Access and Benefit-sharing as Related to Genetic Resources, Sixth Ordinary Meeting of the Conference of the Parties to the Convention on Biological Diversity, held at The Hague, Netherlands, Apr. 7-19, 2002, at para. D (section title: "Other Issues Relating to Access and Benefit-sharing"), available at http:/www.biodiv.org/decisions/ default.aspx $m=\mathrm{m}=\mathrm{COP}-06 \& \mathrm{id}=7198 \& \mathrm{~g}=0$ [hereinafter Decision VI/24] (noting that CBD "has still not been granted observer status" in TRIPS Council).

${ }^{39}$ Trips Council Sets Agenda for June Meeting, BRIDGES WKLY NEWS DIG. (Int'l Ctr. for Trade \& Sustainable Dev., Geneva, Switzerland), May 22, 2002 at 7, 8.

${ }^{40}$ Report of the High Commissioner on the Impact of the Agreement on Trade-Related Aspects of Intellectual Property Rights on Human Rights, U.N. Econimc and Social Council, 52nd Sess., Provisional Agenda Item 4, at para. 68, U.N. Doc. E/CN.4/Sub.2/2001/13 (June 27, 2001) [hereinafter High Commissioner Report]; Res. 2001/21, Sub-Commission on Human Rights, 16th mtg., at para. 9, U.N. Doc. E/LN.4/sub.2/RES/2001/21 (2001) [hereinafter 2001 Sub-Commission Intellectual Property Resolution] (requesting High Commissioner to seek observer status "with the World Trade Organization for the ongoing review of the TRIPS Agreement").

${ }^{41}$ World Intellectual Property Organization (WIPO): General Rules of Procedure, WIPO Pub. No. 399 (FE) Rev. 3, Rule 8(2) (1990); see also Intergovernmental Committee on 
but they have been applied very expansively. For example, the Intergovernmental Committee on Intellectual Property and Genetic Resources, Traditional Knowledge and Folklore ${ }^{42}$ has granted observer status not only to intergovernmental organizations from the biodiversity, PGR, health, and human rights regimes, but also to dozens of international and national NGOs, increasing the ability of non-state intergovernmental actors to influence negotiations among WIPO members. ${ }^{43}$

\section{B. Formal and Informal Partnerships and Information Sharing Mechanisms}

A second mode of interaction among international actors and institutions in the international intellectual property regimes takes the form of formal and informal partnerships in subject areas of shared competence. In some cases, these partnerships are mandated by treaty; in others, more informal relationships arise on an ad hoc basis, as the activities of the two organizations become increasingly interlinked.

An example of treaty-based collaboration is found in Article 68 of TRIPS, which directs the TRIPS Council to "seek to establish . . . appropriate arrangements for cooperation with" WIPO. ${ }^{44}$ The result of these efforts was a 1995 Agreement between WIPO and WTO. ${ }^{45}$ The Agreement requires the two organizations to share information received from their respective members relating to intellectual property laws and regulations; mandates that each organization provide technical and legal assistance to developing countries that are members only of the other organization; and delegates to WIPO certain administrative functions

Intellectual Property and Genetic Resources, Traditional Knowledge and Folklore, Rules of Procedure, WIPO Doc. WIPO/GRTKF/IC/1/2, at para. 8, n.3 (Apr. 5, 2001) ("[E]ach body [in WIPO] shall decide, in a general way, or for a particular sessions or meeting, which other States and [intergovernmental] organizations shall be invited to be represented by observers.").

42 For a detailed review of the IGC's work and supporting documents, see http://www.wipo.int/tk/en/ (last visited Oct. 29, 2004).

${ }^{43}$ See, e.g., Report by the Intergovernmental Committee on Intellectual Property and Genetic Resources, Traditional Knowledge and Folklore, 1st Sess., Geneva, Apr. 30-May 3, 2001, at paras. 2-3, WIPO Doc. WIPO/GRTKF/IC/1/13 (May 23, 2001) (listing observers at first IGC meeting); Report by the Intergovernmental Committee on Intellectual Property and Genetic Resources, Traditional Knowledge and Folklore, 2nd Sess., Geneva, Dec. 10-14, 2001, at paras. 3-4, WIPO Doc. WIPO/GRTKF/IC/2/16 (Dec. 14, 2001) (listing observers at second IGC meeting).

44 TRIPS, supra note 14 , art. 68.

${ }^{45}$ Agreement Between the World Intellectual Property Organization and the World Trade Organization, Dec. 22, 1995, 35 I.L.M. 754. 
contained in TRIPS. ${ }^{46}$ In 1996, the CBD's Conference of the Parties suggested a similar information sharing mechanism by which states parties to both treaties would notify the TRIPS Council of laws and regulations adopted to implement the Biodiversity Convention's intellectual property provisions. $^{47}$

Examples of ad hoc institutional interactions are both more prevalent and more theoretically interesting. Most informally, one organization can unilaterally request another to review a specific subject area or consider a particular perspective. In Decision V/26 on Access to Genetic Resources, for example, the Conference of the Parties invited the WTO "to take into account the fact that the provisions of [TRIPS and the CBD] are interrelated and to further explore this relationship."${ }^{, 48}$ United Nations human rights bodies have made similar unilateral requests, adopting resolutions that urge the WTO to consider the human rights implications of TRIPS. ${ }^{49}$ There is no guarantee, of course, that the requested organizations will respond favorably to these unsolicited requests.

\section{Competition and Cooperation among Actors and Institutions}

A more structured mode of cooperation occurs where one intergovernmental organization submits information to another, either at the request of the recipient organization or one of its member states. In 1999, for example, the TRIPS Council requested written submissions from the

${ }^{46}$ Id. at arts. 2(3) \& 2(4); see also id. at art. 3 (implementing Article 6ter of the Paris Convention for purposes of TRIPS); $i d$. at art. 4 (legal-technical assistance to and technical cooperation with developing countries).

${ }^{47}$ See Convention on Biological Diversity, The Convention on Biological Diversity and the Agreement on Trade-Related Aspects of Intellectual Property Rights (TRIPS): Relationships and Synergies, at para. 58(d), UNEP/CBD/COP/3/23 (Oct. 5, 1996). Organizations can also jointly request information from states, as seen in the COP's request to the CBD's Executive Secretary to undertake "with the help of other international and intergovernmental organizations such as [WIPO] . . . further information gathering and analysis" concerning access and benefit sharing issues. Decision VI/24, supra note 38 , at para. C (section title: "Role of Intellectual Property Rights in the Implementation of Access and Benefit-sharing Arrangements).

48 Convention on Biodiversity, Decision V/26, Access to Genetic Resources, Fifth Ordinary Meeting of the Conference of the Parties to the Convention on Biological Diversity, held at Nairoki, Kenya, May 15-26, 2000, at para. B(2), available at http://www.biodiv.org/decisions/default.asp?lg=0\&dec=V/26 (last visited Oct. 9, 2004).

${ }^{49} 2001$ Sub-Commission Intellectual Property Resolution, supra note 40, at para. 12; see also High Commissioner Report, supra note 40, para. 68 (encouraging ministerial meeting in Doha to "consider establishing closer links between the promotion and protection of human rights and the TRIPS Agreement"). 
FAO and CBD relating to the Council's review of TRIPS Article 27.3(b). ${ }^{50}$ The Council renewed and expanded its request after Doha, seeking information from the secretariats of several intergovernmental organizations concerning their activities related to Article 27.3(b), the relationship between TRIPS and the CBD, and the protection of traditional knowledge and folklore.

More formal work programs can be established when two organizations create a joint legislative agenda to regulate issues at the interface of their jurisdictional mandates. In 2002, for example, the Sixth Conference of the Parties to the CBD sought to enter into a "Memorandum of Understanding" with WIPO to address the intellectual property issues raised by the Convention's traditional knowledge provisions. ${ }^{52}$

Why would CBD member states seek such a memorandum? The answer, at least in part, relates to a competition between the organizations for primacy over a shared policy space. The CBD's Decision VI/20 on Cooperation with Other Organizations, Initiatives and Conventions reflects this competition. ${ }^{53}$ It carves up the domain of genetic resources and traditional knowledge between the two institutions. The decision recognizes the preeminence of WIPO as "the lead specialized agency to address intellectual property rights. ${ }^{\text {"54 }}$ But in the politically contested area of traditional knowledge, the Biodiversity Convention's members claimed supremacy, stating that the CBD "is the primary international instrument with the mandate to address" the biodiversity-related innovations of

${ }^{50}$ See WTO Council for TRIPS, Review of the Provisions of Article 27.3(b), Information from Intergovernmental Organizations, Addendum: FAO, IP/C/W/130/Add.2 (Apr. 12, 1999); WTO Council for TRIPS, Review of the Provisions of Article 27.3(b), Information from Intergovernmental Organizations, Addendum: Secretariat of the Convention on Biological Diversity, IP/C/W/130/Add.1 (Mar. 16, 1999).

${ }^{51}$ WTO Council for TRIPS, Review of the Provisions of Article 27.3(b), Relationship Between the TRIPS Agreement and the Convention on Biological Diversity and Protection of Traditional Knowledge and Folklore, Information from Intergovernmental Organizations, Addendum: Convention on Biological Diversity (CBD), IP/C/W/347/Add.1, at para. 1 (June 10,2002 ) (noting request for information from the CBD, CGIAR, FAO, UNCTAD, UNEP, UPOV, WIPO, and the World Bank).

${ }^{52}$ Convention on Biodiversity, Decision IV/9, Implementation of Article 8(j) and Related Provisions, Fourth Ordinary Meeting of the Conference of the Parties to the Convention on Biological Diversity, held at Bratislava, Slovakia, May 4-15, 1998, at para. 17, available at $\mathrm{http}: / / \mathrm{www}$. biodiv.org/decisions/default.asp?lg=0\&dec=IV/9 (last visited Oct. 5, 2004).

53 See Convention on Biodiversity, Decision VI/20, Cooperation with Other Organizations, Initiatives and Conventions, Sixth Ordinary Meeting of the Conference of the Parties to the Convention on Biological Diversity, held at The Hague, Netherlands, Apr. 719, 2002, available at http://www.biodiv.org/decisions/default.aspx? $\mathrm{m}=\mathrm{COP}$ $06 \&$ id $=7194 \&$ lg=0 (last visited Oct. 5, 2004).

${ }^{54}$ Id. at para. 35. 
indigenous communities. ${ }^{55}$ Unless WIPO acquiesces in this division of labor, however, there is no way to ensure that this claim of preeminence will be respected.

Not all of the relationships between WIPO and the CBD are so contentious. To the contrary, in the area of biodiversity-related innovations, the two organizations have worked in harmony. To encourage states to use patent applications to police the Biodiversity Convention's access and benefit-sharing rules, the CBD Conference of the Parties asked WIPO "to prepare a technical study" on whether additional patent disclosure requirements would be "consistent with obligations in treaties administered by [WIPO]," and "to report its findings to the [Conference]." The WIPO Intergovernmental Committee responded favorably to this request, adopting an accelerated work schedule that allowed it to draft the technical study and present it to the WIPO General Assembly and then to the Conference of the Parties in time for the seventh meeting of the Conference in February $2004 .^{57}$

\section{Conclusion: The Politics of Regime Linkage}

This essay has analyzed an important component of the increasingly dense network of linkages and rules of relationship that the expanding international intellectual property regime has engendered. The examples

55 Convention on Biodiversity, Decision VI/10, Article 8(j) and Related Provisions, Sixth Ordinary Meeting of the Conference of the Parties to the Convention on Biological Diversity, held at The Hague, Netherlands, Apr. 7-19, 2002, available at http://www.biodiv.org/decisions/default.aspx? $\mathrm{m}=\mathrm{COP}-06 \& \mathrm{id}=7184 \& \mathrm{lg}=0$ (last visited Oct. 4, 2004).

56 Intergovernmental Committee on Intellectual Property and Genetic Resources, Traditional Knowledge and Folklore, Certain Decisions of the Sixth Conference of the Parties of the Convention on Biological Diversity, WIPO Doc. WIPO/GRTKF/IC/3/12, Annex, at para. 4, (May 24, 2002). It is uncertain whether this invitation includes an assessment by WIPO of the consistency of disclosure requirements with the TRIPS Agreement. An earlier paragraph in the same document asks for the assistance of WIPO and other international organizations in analyzing the "consistency and applicability of requirements for disclosure of country of origin and prior informed consent in the context of international legal obligations," without limiting those obligations to treaties administered by WIPO. Decision VI/24, supra note 38 at para. C.3.c.

57 Intergovernmental Committee on Intellectual Property and Genetic Resources, Traditional Knowledge and Folklore, Certain Decisions of the Seventh Meeting of the Conference of the Parties to the Convention on Biological Diversity Concerning Access to Genetic Resources and Benefit-Sharing: Memorandum of the Director General, WIPO Doc. WIPO/GRTKF/IC/6/11 (March 5, 2004); Intergovernmental Committee on Intellectual Property and Genetic Resources, Traditional Knowledge and Folklore, Certain Decisions of the Sixth Conference of the Parties of the Convention on Biological Diversity, WIPO Doc. WIPO/GRTKF/IC/3/12 at 1-2 (May 24, 2002). 
discussed reveal that the shift of intellectual property lawmaking into new venues has made the international legal landscape substantially more complex. What began as a regime with a single intergovernmental organization-WIPO - then became a bimodal regime with two predominant organizations - the WTO and WIPO - and has now morphed into a multi-modal or conglomerate regime populated by numerous intergovernmental bodies and networks of regional and bilateral agreements. $^{58}$

The consequences of this proliferation of venues for the future of the international intellectual property regime are still unclear. Two divergent evolutionary pathways are plausible. On the one hand, reviewing the same legal and policy issues in multiple fora may produce delays, inefficiencies, and inconsistent legal norms that inhibit regulatory solutions. On the other hand, such review may ultimately lead to better outcomes by generating a range of preliminary policy responses that prevents any a one organization from prematurely locking in an equilibrium that is sub-optimal or biased toward particular interest groups.

It is too early to make confident predictions about whether the benefits of proliferation will outweigh its costs. Although the strategy of regime shifting has opened up intellectual property lawmaking and dispute settlement to new avenues of influence and enhanced opportunities to link issue areas, it has also increased the likelihood of inconsistent obligations for states and private parties. It is this danger of incoherence that is an especially grave concern for an international legal system whose conflicts rules engender more confusion than certainty, and whose courts and tribunals are still relative neophytes at resolving the difficult issues that such inconsistencies can engender.

${ }^{58}$ See Leebron, supra note 20, at 10, 19 (describing the international trade regime as a "conglomerate type of regime" consisting of "not only of the WTO and bilateral and regional agreements and institutions, but also of informal consultative mechanisms and expectations of behavior that occur on a plurilateral or bilateral basis"); see also Kal Raustiala \& David G. Victor, The Regime Complex for Plant Genetic Resources, 58 INT'L ORG. 277 (2004) (examining the implications of the rising density of international institutions). 